\title{
Long-term stability studies of anode-supported microtubular solid oxide fuel cells
}

\author{
M. A. Laguna-Bercero ${ }^{1 *}$, A. Férriz ${ }^{2}$, Á. Larrea $^{1}$, L. Correas ${ }^{2}$ and V. M. Orera ${ }^{1}$ \\ ${ }^{1}$ Instituto de Ciencia de Materiales de Aragón (ICMA), CSIC- Universidad de Zaragoza, C/ Pedro \\ Cerbuna 12, E-50009, Spain; Phone: +34 876555152; Fax: +34 976761957 \\ ${ }^{2}$ Fundación para el Desarrollo de las Nuevas Tecnologías del Hidrógeno en Aragón, \\ Parque Tecnológico Walqa, Ctra. Zaragoza N330A, km 566, E- 22197 Huesca, Spain \\ Phone: +34 974215258; Fax: +34 974215261
}

[*] Corresponding author, malaguna@unizar.es

\begin{abstract}
A long-term stability study of an anode-supported NiO/YSZ-YSZ-LSM/YSZ microtubular cell was performed, under low fuel utilization conditions, using pure humidified hydrogen as fuel at the anode side and air at the cathode side. A first galvanometric test was performed at $766{ }^{\circ} \mathrm{C}$ and $200 \mathrm{mAcm}^{-2}$, measuring a power output at $0.5 \mathrm{~V}$ of $\sim 250 \mathrm{mWcm}^{-2}$. During the test, some electrical contact breakdowns at the anode current collector caused sudden current shutdowns and start-up events. In spite of this, the cell performance remains unchanged. After a period of 325 hours, the cell temperature and the current density was raised to $873{ }^{\circ} \mathrm{C}$ and $500 \mathrm{mAcm}^{-2}$, and the cell power output at $0.5 \mathrm{~V}$ was $\sim 600 \mathrm{mWcm}^{-2}$. Several partial reoxidation events due to disturbance in fuel supply occurred, but no apparent degradation was observed. On the contrary, a small increase in the cell output power of about 4\%/1000h after 654 hours under current load was obtained. The excellent cell aging behaviour is discussed in connection to cell configuration. Finally, the experiment concluded when the cell suffered irreversible damage due to an accidental interruption of fuel supply, causing a full reoxidation of the anode support and cracking of the thin YSZ electrolyte.
\end{abstract}

Keywords: Solid Oxide Fuel Cell, SOFC, Microtubular, Performance, Durability

\section{Introduction}

Solid oxide fuel cells (SOFCs) are well known electrochemical devices that directly convert the chemical energy of hydrogen-enriched fuels into electricity [1]. Planar and tubular SOFCs are generally used for stationary applications. However, microtubular SOFCs (mSOFCs) are more appropriate for portable applications, as they present rapid start-up times and strong resistance to thermal cycling. The micro-tubular configuration also presents higher volumetric power densities in comparison with standard and tubular designs [2,3]. Among the different mSOFCs configurations that have been studied, anodesupported cells are of interest since the thinner electrolyte allows for a lower operating temperature. As for planar and tubular designs, the most used materials for mSOFC components are: NiO/YSZ (yttriastabilized zirconia) for the anode; YSZ for the electrolyte and LSM (lanthanum strontium manganite) for the cathode of cells operating at temperatures over $700^{\circ} \mathrm{C}$. Furthermore, these mSOFCs have also been operated in the solid oxide electrolyser (SOEC) mode [4]. For intermediate operating temperatures around $550^{\circ} \mathrm{C}$ the most widely used materials are NiO-GDC (gadolinia-doped ceria) for the anode; GDC for the electrolyte and LSCF (lanthanum strontium cobalt ferrite) for the cathode. Some features of mSOFCs comprising their performance under hydrocarbon fuel operation [5,6,7], the resistance to anode redoxcycling [8,9] and thermal cycling [10,11], the effect of gas pressurization [12], the development of hollow fibres [13], and the microtubular stack modelling and design $[14,15]$ have been widely studied. However, there are relatively few studies reported in the literature related to long-period testing of anode-supported mSOFCs under operating conditions.

Durability and reliability are crucial aspects for SOFC applications that depend not only on the thermochemical and thermomechanical compatibility of the cell components, but also on cell processing parameters and design and on operation conditions. Yokokawa et al. reviewed the fundamental mechanisms concerning SOFC durability [16]. In the case of anode-supported cells the dimensional changes associated with redox cycling are of severe concern for the integrity of the cell [17]. Kendall et 
al. performed several cycling studies on anode-supported microtubular cells (Ni/YSZ-YSZ-LSM/YSZ) from Adaptive Materials Inc. [18] including rapid thermal and redox cycling studies of individual cells [19] and also of small cell stacks [20]. They studied the degradation during a relatively short period of 42 hours operation at a constant temperature of $600{ }^{\circ} \mathrm{C}$, and a current density of $0.32 \mathrm{~A} \mathrm{~cm}^{-2}$ [18]. They observed an initial voltage drop of about $1 \%$ over the first 40 hours, and estimated a long-term degradation rate of less than 5\% per 1000 hours. They assumed that some sintering process occurred at this early stage, causing the small but noticeable degradation. Noticeably, resistance of mSOFC to severe and rapid thermal cycles (rates of $100^{\circ} \mathrm{C} \mathrm{min}^{-1}$ ) was outstanding, about $0.056 \%$ voltage drop per cycle at $600^{\circ} \mathrm{C}$. This was also corroborated by Du et al. [11] who studied the thermal stability of individual mSOFCs and portable stacks. These authors reported that after 150 thermal cycles, the cell power output of single cells increased by $7.7 \%$. A similar cell also gained $6 \%$ after 338 thermal cycles. The same authors tested the stack stability for a period of 1000 hours with 15 unscheduled thermal cycles from ambient to operating temperature. They reported an increase in power output of the stack of $11 \%$. Recently, Yamaguchi et al. [21] also reported on the long-term stability of mSOFCs operating at $500{ }^{\circ} \mathrm{C}$. In this case, the cell consisted of a NiO-GDC anode support, with a thin GDC electrolyte and LSCF-GDC as cathode. The long-term stability experiment at $500^{\circ} \mathrm{C}$ was performed under a current load of $169 \mathrm{~mA}$ $\mathrm{cm}^{-2}$ at $0.75 \mathrm{~V}$ for a period of about 100 hours, and a degradation rate of $0.25 \% 100 \mathrm{~h}^{-1}$ was obtained. Finally, Almutairi et al. [22] performed durability studies of some tubes that are components of the integrated-planar solid oxide fuel cell (IP-SOFC) system (Rolls Royce Fuel Cell Systems Ltd). The experiments were carried out at a constant current of $1 \mathrm{~A}$ at $900^{\circ} \mathrm{C}$ for more than $1200 \mathrm{~h}$, and they found an average voltage degradation rate of around $1.5 \%$ per $1000 \mathrm{~h}$.

In the present paper it will be reported on the electrochemical long-term study performed on standard anode-supported $\mathrm{mSOFCs}(\mathrm{NiO} / \mathrm{YSZ}-\mathrm{YSZ}-\mathrm{LSM} / \mathrm{YSZ})$ produced in our laboratory at relatively high temperatures. The typical SOFC performance of these cells is about $600 \mathrm{~mW} \mathrm{~cm}{ }^{-2}$ at $850{ }^{\circ} \mathrm{C}$ under pure humidified hydrogen [23]. In addition, it was previously observed that these cells did not suffer degradation after more than 20 cooling and heating thermal cycles from operating to ambient temperature at temperature rates of about $80^{\circ} \mathrm{C} \mathrm{min}^{-1}$. The cells have also been tested at $850^{\circ} \mathrm{C}$ for SOEC mode operation [24,25] using $70 \% \mathrm{H}_{2} \mathrm{O} / 15 \% \mathrm{H}_{2} / 15 \% \mathrm{~N}_{2}$ as fuel and a current density of $-1 \mathrm{~A} \mathrm{~cm}^{-2}$ at $1.3 \mathrm{~V}$. Studies on the tolerance of these cells against redox-cycling have also been reported [9].

\section{Experimental}

The anode-supported microtubular SOFCs used in this work were produced in our laboratory. The production process was optimised to obtain cells with the appropriate microstructure for good gas phase permeation and high TPB (Triple Phase Boundary) density values and clean and strong interfaces between the cell components. A full description of the production process of these cells, as well as the microstructural description, can be found in references 23 and 24 .

Similar cells have previously been fabricated and used in different SOFC and SOEC experiments $[24,25]$. The YSZ/NiO anode tubular support was prepared by cold isostatic pressing (CIP). Commercial $\mathrm{NiO}$ (Alfa Aesar, 99\%) powders were first ball milled with 2-propanol media to an appropriate particle size of about one micron. Milling consisted of two periods of $2 \mathrm{~h}$, applying an ultrasonic probe to the slurry between them to avoid powder agglomeration. Milled powder was then mixed with commercial YSZ-8YS (Tosoh, 99.9\%) and corn starch as pore former to obtain a final composition of 50\% in volume of metallic Ni and YSZ. Final anode porosity is about 50\%. Polyvinyl alcohol was finally added as binder and the powders were shaped by CIP at $200 \mathrm{MPa}$ for 5 min using a tubular latex coating and a steel rod to form the lumen. The tube was pre-sintered at $1000^{\circ} \mathrm{C}$ in air. The outer surface of the tubes was spray coated with YSZ (TZ-8Y from Tosoh) to produce an electrolyte layer of approximately $15 \mu \mathrm{m}$ thick after the co-sintering of the anode and electrolyte components at $1350^{\circ} \mathrm{C}$ for $2 \mathrm{~h}$. After sintering the tubular half-cell has typically $100 \mathrm{~mm}$ length, $300 \mu \mathrm{m}$ thickness and $2.4 \mathrm{~mm}$ inner diameter. The LSM A-site deficient manganite $\left(\mathrm{La}_{0.8} \mathrm{Sr}_{0.2}\right)_{0.98} \mathrm{MnO}_{3}$ (Fuelcell Materials) was used for the oxygen electrode. A composite of LSM/YSZ (50/50 wt \%) was used to deposit a functional layer on the electrolyte surface and a composite of LSM/YSZ (80/20 wt\%) for the current collector layer. Both functional and current collector layers were deposited by the dip-coating method to a total thickness of about $40 \mu \mathrm{m}$.

In figure 1 a diagram of the test rig is shown. Fuel gas is introduced into the anode tube through an alumina tube sealed to the cell tube with a ceramic paste. Pt wires and Pt paste were used for current collection at the cathode side. On the anode side, Ni foam is tightly placed inside the anode tube to provide electrical contact between the cermet tube and the collecting Pt wire whilst still allowing fuel to 
flow. In the cathode side LSM paste (terpineol-based, for the LSM/YSZ electrode) was used to improve current collection.

As can be seen in figure 1, the cell and electrical leads are placed inside a small tubular furnace. The active area of the cell was limited to $\sim 1 \mathrm{~cm}^{2}$ in order to get a homogeneous temperature over the cell active area. It is important to remark that with this rig configuration, seals are placed well outside of the furnace, in such a way that the temperature in the seals is always below $200{ }^{\circ} \mathrm{C}$. Due to the small dimensions of the furnace, convection cooling and the cooling effect of the gas flow, the temperature in the cell active area differs from that of the furnace reference. Thus, a thermocouple was also placed next to the oxygen electrode of the cell in order to display the cell temperature.

For the durability experiments the cell was firstly heated up to $800^{\circ} \mathrm{C}$ (furnace temperature), which corresponds to a cell temperature of about $766^{\circ} \mathrm{C}$, with nitrogen atmosphere at the fuel electrode. Then, the fuel atmosphere was switched to pure hydrogen saturated with deionised water vapour at room temperature $\left(\sim 3 \% \mathrm{H}_{2} \mathrm{O}\right)$, causing the nickel oxide reduction to metallic nickel. The cell was left to stabilize for a period of 12 hours with gas flows of $100 \mathrm{ml} \mathrm{min}^{-1}$ of $3 \%$ humidified pure $\mathrm{H}_{2}$ as fuel and $200 \mathrm{ml} \mathrm{min}{ }^{-1}$ of synthetic air at the oxygen electrode. Then polarization curves and impedance spectroscopy tests were carried out throughout the operating time according to the following protocols. Electrochemical measurements were performed using a Zahner Zennium (ZAHNER-Elektrik GmbH \& Co.KG, Germany) electrochemical workstation. Galvanostatic measurements were performed at constant currents of $200 \mathrm{~mA} \mathrm{~cm}^{-2}$ and $500 \mathrm{~mA} \mathrm{~cm}{ }^{-2}$, for cell temperatures of $766{ }^{\circ} \mathrm{C}$ and $873^{\circ} \mathrm{C}$, respectively. $j$-V (current density-voltage) curves were collected from OCV (open circuit voltage) to $0.5 \mathrm{~V}$ and to OCV again, using a scan rate of $5 \mathrm{mV} \mathrm{s}^{-1}$.

Electrochemical impedance spectroscopy (EIS) measurements were performed using a sinusoidal amplitude signal of $20 \mathrm{mV}$ in the frequency range of $100 \mathrm{kHz}$ to $0.1 \mathrm{~Hz}$. EIS data were analysed using an equivalent circuit composed of $L R_{\text {ohm }}\left(R_{l} Q_{1}\right)\left(R_{2} Q_{2}\right)$ (as shown in the inset of figure $3 \mathrm{~b}$ ) where $\mathrm{R}_{\mathrm{ohm}}$ represents the pure ohmic resistance. Each of the parallel circuits of resistance $R_{i}$ and constant phase element $Q_{i}$ accounts for the respective depressed semicircle going from high to low frequencies. A parasitic inductance $L$ was added to take into account the contribution of the equipment.

After 654 hours of fuel cell operation an accidental interruption in the fuel supply during several hours produced an irreversible cell breakdown. A post-mortem microstructural cell analysis was performed using a Scanning Electron Microscope (SEM). Experiments were performed using an accelerating voltage of 0.8 to $3 \mathrm{kV}$ using a Merlin FE-SEM (Carl Zeiss). For the elemental X-ray analyses the microscope is equipped with an INCA Oxford Instruments energy dispersive X-ray spectroscopy (EDS) analytical system.

\section{Results and discussion}

The long-term stability voltage curve of the cell tested under current load is shown in figure 2 for a total period of 650 hours. In this figure, two regions are clearly observed. During the first 325 hours, the cell was operated under $200 \mathrm{~mA} \mathrm{~cm}{ }^{-2}$ load, and the average temperature of the cell was $766^{\circ} \mathrm{C}$. The initial voltage was $720 \mathrm{mV}$ and this value increased up to $738 \mathrm{mV}$ after the initial 25 hours due to the LSM activation, as will be discussed later. For the next 300 hours several fast voltage shutdown and start-up events occurred. The rapid voltage fluctuations that can be observed in the initial stage were associated with a reversible break in the $\mathrm{Ni}$ foam anode contact, presumably caused by volume accommodation of $\mathrm{Ni}$ foam due to Ni partial reoxidation. The anode contact was rebuilt and then voltage fluctuations disappeared. No apparent cell performance degradation was observed after these severe transients in the load current, confirming the excellent resistance of mSOFC to electrical shut-down/start-up cycling [18].

Prior to the long-term experiment, EIS at OCV and $j$-V measurements were performed, as shown in figure 3 and figure 4 , respectively. Both EIS and $j$-V measurements were periodically collected during the durability study. The data shown on figures 3 and 4 correspond to cell operating times of $0,25,325$ and 650 hours. From EIS curves in figure 3 (a) it is noteworthy that the polarization resistance of the cell as given by the low frequency intersection with the $\mathrm{x}$-axis, was significantly decreased after the first 25 hours of operation, typically attributed to LSM activation at $750-800{ }^{\circ} \mathrm{C}$ [26,27].. A detailed study of the EIS data, acquired at different operating times, using equivalent circuits was also performed. The EIS curves were fitted to the equivalent electrical circuit given in the inset in figure 3 . The $(R 1 Q 1)$ and $(R 2 Q 2)$ circuit components are centred at frequency values around $2000 \mathrm{~Hz}$ and $10 \mathrm{~Hz}$, respectively. Regarding the ohmic $R_{\text {ohm }}$ component, given by the high frequency EIS curve intersection with x-axis in figure 3 , which is plotted in figure 5 , it is observed that the ohmic resistance values remain practically 
constant with operating time around a value of $0.32 \Omega \mathrm{cm}^{-2}$. The $R_{\mathrm{ohm}}$ value is also consistent with that expected for a cell with a thin $\sim 15 \mu \mathrm{m}$ YSZ electrolyte. According to previous studies, the low frequency $(R 2 Q 2)$ component is tentatively associated to the oxygen electrode, whereas the $(R 1 Q 1)$ component is associated to the anode contribution [21] The variation of $R 1$ and $R 2$ values over the operating time are plotted in figure 6 . The observed small deviations from the average were associated with cell temperature changes, and no degradation was detected over time. The only significant observed deviation from average values was the $R 2$ decrease after the initial 25 hours of operation. This decrease in the polarization resistance was induced by the cathodic current passage which, as it is well known, produces an enhancement in the performance of LSM cathodes [26,27]. Activation of the LSM cathode is more noticeable at temperatures under $800^{\circ} \mathrm{C}$, where the electronic conduction of the LSM decreases. Finally, the capacitance values (obtained from Q elements using the equations described in reference 28) are plotted in figure 7. Similarly to $R$ values, $C 1$ and $C 2$ do not suffer significant variation as a function of the operating time. Only a small decrease was observed during the first $25 \mathrm{~h}$, and this was attributed to the LSM activation.

We obtained a cell steady state performance under current load after a period of about 25 hours operation was obtained. The same effect is also observable in the $j$-V experiments. In figure 4 we give the $j$-V curves taken at $0,25,325$ and 650 hours of operation. A small increase in the output power was observed after the first hours of operation. Although the reverse scan (from $0.5 \mathrm{~V}$ to OCV) is not shown in the figure, slightly higher current density values (a difference of $\sim 20 \mathrm{~mA} \mathrm{~cm}-2$ at $0.7 \mathrm{~V}$ and $25 \mathrm{~h}$ ) than in the shown scan (from OCV to $0.5 \mathrm{~V}$ ) were measured, with the effect being particularly noticeable during the first hours of operation. This evidence showed a transient effect taking place during the first $25 \mathrm{~h}$ confirming our hypothesis of a cathode electrode microstructural reorganization during the initial stage, leading to an increase in the cell performance. This effect disappeared after the first 25 hours of operation. In addition, the kink observed at current densities of about $300 \mathrm{~mA} \mathrm{~cm}^{-2}$ for the $j-\mathrm{V}$ curves was associated with a calibration problem of the equipment. Nevertheless, this jump is noticeable when the cell performance is low but almost negligible at higher temperatures $\left(873^{\circ} \mathrm{C}\right)$, where the performance of the cell is enhanced.

Looking at the EIS data in figure 3 (a), it was observed that there is no apparent ASR degradation from 25 to 325 hours of cell operation. After 325 hours, current density was increased to $500 \mathrm{~mA} \mathrm{~cm}^{-2}$, and the average temperature of the cell was also increased to $873{ }^{\circ} \mathrm{C}$. In some regions of the graph (figure 2 ), a slow and constant voltage decay was detected. This effect was associated with an oxygen partial pressure increase at the anode side. In fact the voltage decay is associated to the presence of some water drops in the exhaust channel associated with steam generation. Inefficient steam evacuation induces the oxidation of $\mathrm{Ni}$ at the current collector, or even the formation of $\mathrm{Ni}$ hydroxides at the anode side [29]. In fact, once water drops were removed from the exhaust pipe the steady voltage values were immediately recovered. In figure 3 (b) it can also be observed that there is no apparent ASR degradation from 325 to 650 hours of operating time.

In table 1, average voltage values at the initial stage, and after 25, 325, 340 and 640 hours of cell operation are presented, as well as the estimated degradation rate of the cell. If the initial activation stage previously discussed is not taken into account for these calculations, the degradation rate expressed in SOFC standards (\% voltage decay per 1000 hours) was around $-4 \% 1000 \mathrm{~h}^{-1}$. This remarkable result is also in concordance with those obtained in the studies of Du et al. [11], where they observed an $11 \%$ increase of power density in their microtubular SOFC stack after 1000 hours of operation. Note that for planar SOFC cells a degradation rate of $1 \% 1000 \mathrm{~h}^{-1}$ is considered to be an excellent low degradation rate [30]. Our mSOFCs present a small improvement instead of degradation over long-term operation.

According to those previous studies [11], the small increase of fuel cell performance with the operating time could be tentatively ascribed to some beneficial microstructural changes occurring in the electrodes under current load. These microstructural changes could improve gas permeation and/or electrical connectivity.

After 654 hours of operation, an unexpected hydrogen fuel supply failure was detected leading to irreversible cell damage and as a consequence the voltage dropped to 0V. SEM microstructural analysis including microscopic X-ray elemental analysis after breakdown revealed an almost complete anode reoxidation and as a consequence strong mechanical damage of the cell (figure 8). Unfortunately, due to this unplanned cell damage it was not possible to perform the detailed study of the electrode microstructure evolution after the long-term operation, but some valuable information can be obtained from the SEM micrographs. For comparison, a transverse cross-section SEM image of a non-operated identical cell is shown in figure 8 (a). The porosity observed in the YSZ electrolyte consists of 
unconnected pores as indicated by the fact that OCV values were about the same as predicted by the Nernst equation. Figures 8 (b) and (c) correspond to transverse cross-sections of two different parts of the microtubular cell after breakdown. In figure 8 (b), in addition to the evident coarsening of the Ni/YSZ cermet microstructure, it was observed a severely damaged area where the volume expansion, associated with the complete reoxidation of the anode, produced both debonding at the anode-electrolyte interface and transversal cracking of the electrolyte and LSM/YSZ cathode. It is believed that development of tensile stresses in the electrolyte thin film associated with anode volume expansion is presumably the origin of the transverse cracking. However, there were some other areas where the cell microstructure remained unaltered, showing no apparent mechanical degradation, as for example in the region represented in figure 8 (c). These findings confirm that the good adhesion at the electrolyte-electrode interfaces, which is a characteristic of these cells, has been conserved after the durability test. In addition, no significant microstructural changes, besides the delamination of the Pt current collector, were observed in these areas where anode reoxidation was not so severe.

As a summary, the results of the duration experiment are in agreement with the expected excellent resistance of the microtubular cells to fast start-up and shutdown cycles. Furthermore, these cells present excellent resistance to rapid thermal cycling, as was previously reported for cells produced in our laboratory and also in other laboratories (refs. 11, 19, 23). This is a convenient behaviour for portable applications demanding rapid electrical shutdown cycles. The strong resistance to these rapid changes seems to be related to the mechanical properties of the small tubes, which are more resistant to thermal expansion and contraction events than other configurations. It could be also related to the fact that the tubes are mechanically supported at the tube ends by loose-fitting connections, which decreases the stress field developed at the fixed connection used in other SOFC geometries.

The long-term durability is also remarkable. The degradation rate for planar SOFCs is usually above $+1 \% 1000 \mathrm{~h}^{-1}$ [30]. The long-term degradation in planar SOFCs is typically associated with impurities coming from hot sealing that, in this case, are at cell temperature. However, in the micro-tubular configuration low temperature sealing can be used and, as a consequence, lower diffusion of Si and other species into the cells is expected, possibly being the reason for the better long-term stability of the microtubular cells.

As expected for anode-supported cells, the resistance of the cell to fuel failure events is relatively poor. The low tolerance to reoxidation events remains as the main weak point of the cells.

\section{Summary}

An anode-supported NiO/YSZ-YSZ-LSM/YSZ micro-tubular cell produced in our laboratory were tested under current load for a total period of 650 hours at relatively high temperatures. The test included $j$-V curve measurements and impedance analysis. Moderate temperature and current load conditions were firstly selected at $766{ }^{\circ} \mathrm{C}$ and $200 \mathrm{~mA} \mathrm{~cm}{ }^{-2}$. During the first 25 hours, the cell underwent an acclimatization period due to LSM/YSZ activation and power density of the cell increased ( $3 \%)$. For the next 300 hours of operation, no apparent degradation was observed at this stage from both $j$-V curves and EIS data in spite of the undesired electrical contact problems leading to fast shutdowns and start-up cycles. Severe conditions were subsequently applied, where cell temperature was increased to $873^{\circ} \mathrm{C}$ and current density was fixed at $500 \mathrm{~mA} \mathrm{~cm}^{-2}$. The degradation rate expressed in SOFC standards $(\%$ per 1000 hours) was around $-4 \% 1000 \mathrm{~h}^{-1}$. This improvement in cell behaviour over the operating time is in concordance with previous findings for some microtubular cells. It is believed that the low temperature sealing used during the cell test is the reason for the excellent long-term stability of the cells. The cells present an excellent resistance to rapid electrical and thermal cycling in contrast to a poor tolerance to reoxidation events.

\section{Acknowledgements}

The authors thank grants MAT2009-14324-C02 and MAT2012- 30763, financed by the Spanish Government (Ministerio de Ciencia e Innovación) and Feder program of the European Community, and also grant GA-LC-035/2012, financed by the Aragón Government and La Caixa Foundation for funding the project. M.A.L.-B. thanks the JAE program (CSIC) for financial support. The authors also thank Jorge Silva for cell production. Lastly, the use of Servicio de Microscopia Electronica (University of Zaragoza) is acknowledged. 


\section{Tables}

Table 1. Evolution of the voltage and degradation rate as a function of the operating time.

\begin{tabular}{|c|c|c|c|c|}
\hline $\begin{array}{l}\text { Temperature } \\
\left({ }^{\circ} \mathrm{C}\right)\end{array}$ & $\begin{array}{l}\text { Time } \\
\text { (h) }\end{array}$ & $\begin{array}{l}\text { Current density } \\
\qquad\left(\mathrm{mA} \mathrm{cm} \mathbf{c m}^{-2}\right)\end{array}$ & $\begin{array}{c}\text { Voltage } \\
(\mathrm{mV})\end{array}$ & $\begin{array}{l}\text { Degradation rate } \\
\qquad\left(\% 300 \mathrm{~h}^{-1}\right)\end{array}$ \\
\hline 774 & 0 & 200 & 720 & - \\
\hline 766 & 25 & 200 & 738 & - \\
\hline 766 & 325 & 200 & 754 & -2.12 \\
\hline 873 & 340 & 500 & 808 & - \\
\hline 873 & 640 & 500 & 812 & -0.49 \\
\hline
\end{tabular}

\section{Figure Captions}

Figure 1. Schematic of the micro-tubular test rig.

Figure 2. Long-term galvanostatic study of the micro-tubular fuel cell. Cell voltage versus operating time.

Figure 3. (a) EIS measurements at OCV conditions for the initial stage, after 25 hours and after 325 hours of operation. (b) EIS measurements at OCV conditions after 325 and 650 hours of operation.

Figure 4. $j$-V curves obtained during the long-term galvanostatic experiment.

Figure 5. Variation of the ohmic resistance as a function of the operating time.

Figure 6. Variation of R1 and R2 resistances as a function of the operating time.

Figure 7. Variation of $\mathrm{C} 1$ and $\mathrm{C} 2$ capacitances as a function of the operating time.

Figure 8. SEM micrographs corresponding to (a) a non-operated cell. (b) and (c) SEM micrographs after 650 hours operation and breakage of the cell. (b) shows a fully anode reoxidated region showing electrolyte cracking, (c) an undamaged cell area.

\section{References}

[1] S.C. Singhal, K. Kendall, High Temperature SOFCs: Fundamentals, Design and Applications, Elsevier, 2003.

[2] V. Lawlor, S. Griesser, G. Buchinger, A. G. Olabi, S. Cordiner, D. Meissner, J. Power Sources 2009, $193,387$.

[3] K. S. Howe, G. J. Thompson, K. Kendall, J. Power Sources 2011, 196, 1677. 
[4] M. A. Laguna-Bercero, J. Power Sources 2012, 203, 4.

[5] G. Buchinger, P. Hinterreiter, T. Raab, S. Griesser, R. Claassen, D. P. Claassen, W. Sitte, D. Meissner, J. Fuel Cell Sci. Tech. 2006, 3, 280.

[6] F. Calise, G. Restucccia, N. Sammes, J. Power Sources 2011, 196, 301.

[7] A. Dhir, K. Kendall, J. Power Sources 2008, 181, 297.

[8] K. Kendall, C. M. Dickwal, W. Bujalski, ECS Trans. 2007, 7, 1521.

[9] H. Monzón, M. A. Laguna-Bercero, Int. J. Hydrogen Energy 2012, 37, 7262.

[10] P. Sarkar, L. Yamarte, H. Rho, L. Johanson, Int. J. Appl. Ceram. Technol. 2007, 4, 103.

[11] Y. Du, C. Finnerty, J. Jiang, J. Electrochem. Soc. 2008, 155, B972.

[12] S. Hashimoto, H. Nishino, Y. Liu, K. Asano, M. Mori, Y. Funahashi, Y. Fujishiro, J. Electrochem. Soc. 2008, 155, B587.

[13] M. H. D. Othman, N. Droushiotis, Z. Wu, G. Kelsall, K. Li, Adv. Mater. 2011, 23, 2480.

[14] N. Watanabe, T. Ooe, T. Ishihara, J. Power Sources 2012, 199, 117.

[15] Y. Funahashi, T. Shimamori, T. Suzuki, Y. Fujishiro, M. Awano, T. Araki, J. Fuel Cell Sci. Tech. 2010, 7, 051012.

[16] H. Yokokawa, H. Tu, B. Iwanschitz, A. Mai, J. Power Sources 2008, 182, 400.

[17] D. Sarantaridis and A. Atkinson, Fuel Cells 2007, 3, 246.

[18] K. Kendall, Ch. M. Dickwal, ECS Tans. 2009, 25, 899.

[19] K. Kendall, Ch. M. Dikwal and W. Bujalski, ECS Tans. 2007, 7, 1521.

[20] K. Howe and K. Kendall, ECS Tans. 2011, 35, 419.

[21] T. Yamaguchi, K. V. Galloway, J. Yoon, N. M. Sammes, J. Power Sources 2011, 196, 2627.

[22] G. Almutairi, K. Kendall, W. Bujalski, Int. J. Low-Carbon Tech. 2012, 7, 63.

[23] R. Campana, R.I. Merino, A. Larrea, I. Villarreal, V.M. Orera, J. Power Sources 2009, 192, 120.

[24] M.A. Laguna-Bercero, R. Campana, A. Larrea, J.A. Kilner, V.M. Orera, Fuel Cells 2011, 11, 116.

[25] M. A. Laguna-Bercero, R. Campana, A. Larrea, J. A. Kilner, V. M. Orera, J. Electrochem. Soc. 2010, 6, B852.

[26] S. P. Jiang, J. G. Love, Solid State Ion. 2003, 158, 45.

[27] Y. D. Zhen, S. P. Jiang, J. Electrochem. Soc. 2006, 153, A2245.

[28] J. Fleig, Solid State Ion. 2002, 150, 181.

[29] W. Z. Zhu, S. C. Deevi, Mat. Sci. Eng. 2003, A362, 228.

[30] N. Christiansen, S. Primdahl, M. Wandel, S. Ramousse, A. Hagen, Proc. 10th European SOFC Forum (Eds. F. Lefebvre-Joud, E. Bouyer, J. Kiviaho, J. Laurencin, F. Le Naour, J. Mougin, M. Petitjean), Lucerne, Switzerland, 2012, 03-A04, pp. 11. 